\title{
LA INICIATIVA LEGISLATIVA EN EL ORDENAMIENTO ESPAÑOL
}

\author{
POR \\ RAMON PUNSET \\ Departamento de Derecho Político \\ Universidad de Oviedo
}

\begin{abstract}
SUMARIO
INTRODUCCIÓN.-I. INICIATIVAS POPULAR Y REGIONAL: 1. La iniciativa legislativa popular. 2. La iniciativa legislativa de las Asambleas de las Comunidades Autónomas.-II. INICIATIVAS PARLAMENTARIA Y GUBERNAMENTAL: 1. La iniciativa legislativa parlamentaria. 2. La iniciativa legislativa gubernamental.

3. Iniciativa legislativa y forma de gobierno.
\end{abstract}

\section{INTRODUCCION}

Este trabajo pretende analizar las diversas clases de iniciativa legislativa en el ámbito estatal: la iniciativa popular, la de las Asambleas regionales, la de las Cámaras de las Cortes Generales y la del Gobierno. Por este mismo orden de importancia. Intencionadamente, se ha dejado de lado la iniciativa autonómica y la de reforma estatutaria, habida cuenta de su especificidad objetual.

Como instrumentos imprescindibles se han utilizado la Constitución, los Estatutos vigentes, el Reglamento del Parlamento de Cataluña y los del Congreso y el Senado, éstos aún provisionales. Mas, para que el trabajo tuviera mayor fuste, hubiera sido preciso, aparte de que la Constitución no fuera tan joven, que todos los Estatutos de Autonomía posibles hubieran sido promulgados; y lo mismo los Reglamentos de las Asambleas regionales, la ley de iniciativa popular, los Reglamentos definitivos de las Cámaras de las Cortes y la ley del Gobierno y la Administración. No obstante, existen suficientes cuestiones de interés como para que, incluso sin toda esa normativa, valga la pena este intento de sistematizar y dilucidar (tarea propia de los juristas) una rica problemática, de trascendencia actual y futura. 


\section{INICIATIVAS POPULAR Y REGIONAL}

La participación del Cuerpo Electoral del Estado y de las Asambleas legislativas de las Comunidades Autónomas en el procedimiento de elaboración de las leyes formales resulta, sobre todo en el primer caso, de menguada entidad, pero plantea numerosos problemas teóricos y prácticos. Empecemos por decir que el desarrollo de las normas constitucionales sobre procedimiento legislativo corresponde en exclusiva al Reglamento de cada Asamblea de las Cortes Generales (arts. 87.1 y 89.1: aunque sólo, naturalmente, respecto de la fase procesal pertinente). Dado que la aprobación de los Reglamentos se realiza de manera autónoma por cada Cámara y requiere la mayoría absoluta de sus componentes, se comprenderá la libertad con que, institucionalmente, las Asambleas regulan la participación -0 , por mejor decir, los efectos de la participación constitucionalmente conferida- de otros órganos o sujetos en el ejercicio de la función legislativa. Dicho esto, vayamos al objeto concreto de nuestro trabajo.

\section{La iniciativa legislativa popular}

El artículo 23.1 de la Constitución establece que los ciudadanos tienen el derecho a participar en los asuntos públicos, directamente o por medio de representantes. Sin embargo, la articulación posterior de la participación ciudadana directa en el procedimiento legislativo ordinario ha sido montada por el propio constituyente de modo sumamente restrictivo, pues, ausente el Cuerpo Electoral estatal de toda intervención en la aprobación de las leyes ordinarias ${ }^{1}$, su papel se reduce a la presentación, en condiciones muy severas, de proposiciones de ley a través del instituto de la iniciativa popular (art. 87.3), cuya regulación compete a una ley orgánica en lo concerniente a sus formas de ejercicio y requisitos y a los Reglamentos de las Cámaras (fundamentalmente al del Congreso) en lo que atañe a sus efectos internos: toma en consideración o rechazo, tramitación, modificaciones, rehabilitación en el supuesto de finalización de la legislatura, etc. Veamos con detenimiento estas cuestiones:

A) El número de suscriptores exigido por el artículo 87.3 de la Constitución (500.000) es un número mínimo, pudiendo, por tanto, la ley reguladora a que se remite dicho precepto requerir un número mayor, aunque dentro de términos razonables, que no impidan el efectivo ejercicio de la iniciativa. La Constitución de 1931 se mostraba aún más severa, exigiendo el 15 por 100 de los electores (art. 66.III).

${ }^{1}$ Nótese que el referéndum consultivo del art. 92 no constituye ninguna fase del procedimiento legislativo, al no girar la consulta sobre un texto legislativo, sino sobre «decisiones políticas de especial trascendencia», y que en los referendos del art. 151 los llamados a pronunciarse son los cuerpos electorales de cada provincia. 
B) Además de los límites materiales contemplados en el artículo 87.3 y de la exclusión implícita contenida en el artículo 166 (reforma constitucional), queda también vedada la iniciativa popular en lo relativo a Presupuestos Generales del Estado (art. 134.1 y 5) y planificación de la actividad económica (art. 131). De otra parte, este género de iniciativas se halla igualmente comprendido dentro del ámbito de aplicación del artículo 134.6, que exige la conformidad gubernamental para la tramitación de «toda proposición... que suponga aumento de los créditos o disminución de los ingresos presupuestarios».

C) Nuestra Constitución no especifica si se trata de una iniciativa simple (no articulada) o formulada (como hace, por ejemplo, en este segundo sentido el art. 71.II de la Constitución italiana), remitiéndose a la ley orgánica de desarrollo; omisión y remisión significativas, en las que cabe encontrar fundamento para denegar el ejercicio efectivo de la iniciativa hasta la promulgación de la mencionada ley ${ }^{2}$.

D) La iniciativa popular se ejerce mediante «la presentación de proposiciones de ley» (art. 87.3), cuya tramitación «se regulará por los Reglamentos de las Cámaras» (art. 89.1). Ahora bien: dado que el Congreso es siempre la Cámara que inicia el procedimiento legislativo (arts. 87.2, 88, 89.2, 90.1 y 134.3 y también en este caso, aunque no se diga expresamente), a su Reglamento compete articular los elementos de la citada tramitación. ¿Con qué libertad? El problema radica aquí en el carácter del trámite procedimental denominado toma en consideración. ¿Resulta obligatorio en términos constitucionales y a fin de dotar de sustancia al instituto de la iniciativa legislativa admitir todas las proposiciones? La cuestión no sólo afecta a las de origen popular, sino también a las de procedencia regional y senatorial. J. A. Santamaría Pastor, que propugna la supresión del referido trámite respecto de toda clase de proposiciones (a excepción de las debidas a los diputados), escribe: «... la iniciativa es un acto de voluntad cuyo único efecto es el de poner en marcha vinculantemente para las Cortes el procedimiento legislativo: técnicamente, es el acto de iniciación de un procedimiento, que obliga a tramitar la propuesta y a resolver sobre ella... Este acto de voluntad puede provenir de un órgano ajeno al Parlamento mismo, vinculándole a tramitar el proyecto o proposición en los propios términos en que fue presentado...». $\mathrm{Y}$ respecto a las proposiciones de origen popular, se pronuncia por su «admisibilidad automática», «sin necesidad de toma en consideración por el Congreso de los Diputados...; la iniciativa se consolida en este caso con la mera reunión

\footnotetext{
${ }^{2}$ Sobre similar problema en Italia, donde la ley reguladora del instituto se aprobó sólo en 1970, véanse las referencias bibliográficas al debate doctrinal en F. Cuocolo, «Iniziativa legislativa», en Enc. del Dir., t. XXI, Giuffrè, Milán, 1971, pág. 630. Idéntico fundamento que el aducido en el texto proporciona el examen de la elaboración del artículo 87.3, cuya redacción difiere de la adoptada por los autores del art. 80.4 del Anteproyecto constitucional: «Podrán someterse al Congreso proposiciones de ley articuladas y motivadas, con las firmas acreditadas de quinientos mil electores...» (BOC de 5-I-1978). Este tenor, que hubiera permitido el ejercicio directo e inmediato de la iniciativa popular, fue sustituido por la versión actual en la Comisión de Asuntos Constitucionales y Libertades Públicas del Congreso (Diario de Sesiones de 2-VI-1978, págs. 2927-2928).
} 
de las firmas y la presentación del texto correspondiente» ${ }^{3}$. Frente a esta tesis cabe aducir los siguientes argumentos:

En primer lugar, la iniciativa legislativa es una facultad consistente sólo en la presentación de proposiciones de ley. Lo dice la Constitución misma en el artículo 87.3. Ahora bien: es cierto que la presentación de una proposición produce como efecto la puesta en marcha vinculantemente para la Asamblea del procedimiento legislativo: planteada en forma válida la proposición, la Cámara queda saisie por ella, esto es, obligada a pronunciarse al propósito ${ }^{4}$. Pero, en segundo lugar, esta vinculación no alcanza más que a la fase introductoria de tal procedimiento, que se abre con el ejercicio de la iniciativa y se cierra, en el caso de las proposiciones, con el trámite de la toma en consideración: pretender agotar esa fase en la mera presentación, de modo que las proposiciones válidamente suscritas accedieran directamente a la fase constitutiva o central, no sólo suplantaría la voluntad de la Cámara, que es quien, mediante su Reglamento, ha de articular la tramitación de las proposiciones (art. 89.1), sino que además otorgaría a los órganos o sujetos dotados de iniciativa una potestad legislativa que no les corresponde (art. 66.2) ${ }^{5}$. La iniciativa no es un acto de potestad legislativa, ni el poder de proponer cabe asimilarse al de disponer, «el cual comienza y acaba dentro del órgano al que compete la adopción de la ley» ${ }^{6}$. Por todo ello, y en tercer lugar, el trámite de la toma en consideración, sobre resultar perfectamente constitucional a tenor de la remisión realizada por el artículo 89.1, e igualmente con base en el artículo 66.2, lo es también en cuanto no perjudica de ninguna manera el ejercicio del derecho de iniciativa que la Constitución reconoce, puesto que no condiciona la presentación de proposiciones, sino que se limita a operar como un requisito de procedibilidad de las mismas ${ }^{7}$, libremente apreciada, eso sí, por la Cámara.

3 J. A. Santamaría Pastor, en F. Garrido Falla y otros, Comentarios a la Constitución, Civitas, Madrid, 1980 , págs. 884 y sigs. Los subrayados son del autor citado.

4 "Ce qui caractérise précisément le droit d'initiative: une Chambre, saisie d'une proposition..., ne peut en être dessaisie que par le retrait opéré par l'auteur lui-même ou par un vote de rejet» (Larcher, L'initiative parlementaire en France, París, 1896, pág. 31, apud S. Galeotti, Contributo alla teoria del procedimento legislativo, Giuffrè, Milán, 1957, pág. 244, n. 17).

${ }_{5}$ Para este último argumento, véase P. G. Lucifredi, L'iniziativa legislativa parlamentare, Giuffrè, Milán, 1968, págs. 17 y 18.

S. Galeotti, op. cit., pág. 186, recogiendo una conocida tesis, ampliamente aceptada, de Carré de Malberg, Contribution à la Théorie générale de l'Etat, I, Sirey, París, 1920, página 379.

${ }^{2}$ Cfr. Lucifredi, op. cit., pág. 155. En realidad, la tesis de Santamaría Pastor está construida, tal y como su propio autor reconoce, con la finalidad de resolver «el polémico tema planteado en la actualidad acerca de la admisibilidad de las enmiendas a la totalidad formuladas a las proposiciones de ley tomadas en consideración» (loc. cit., pág. 885, n. 8). Sobre esta contradicción, que no altera lo más mínimo los argumentos que hemos aducido en el texto y que atestigua simplemente la incoherencia con que en este punto está redactado el Reglamento Provisional del Congreso, véase J. F. Merino Merchán, «Enmienda a la totalidad a una proposición de ley. Necesidad de una reforma de los reglamentos de las Cámaras legislativas», en Revista del Departamento de Derecho Político, UNED, núm. 7, 1980 , págs. 167 y sigs., el cual propone un tratamiento restrictivo de dicha facultad reglamentaria de enmienda y su supresión en el Reglamento definitivo (como así parece que 
No hay duda, pues, de la licitud constitucional del instituto de la toma en consideración ni de la corrección jurídica de la consiguiente eventualidad del rechazo de las proposiciones de ley de origen popular ${ }^{8}$.

E) Las proposiciones han de presentarse ante la Mesa del Congreso (art. 92.4 del Regl. Prov.). En el texto, ya dictaminado, que la Comisión de Reglamento de nuestra Cámara Baja propone al Pleno de la Asamblea se exige (art. 124) que vayan "acompañadas de una Exposición de Motivos y de los antecedentes necesarios para pronunciarse sobre ellas», con expresión idéntica a la empleada por el artículo 88 constitucional para los proyectos; pero es evidente que, de prosperar esta redacción, se contravendría lo dispuesto en el artículo 87.3 de la Constitución, que remite a una ley orgánica y no al Reglamento del Congreso la normación de las «formas de ejercicio y requisitos de la iniciativa popular para la presentación de proposiciones de ley», por lo que el futuro precepto reglamentario habría de interpretarse como exclusivamente referido a las proposiciones de origen congresual (así lo confirma, además, el propio texto del Dictamen, cuyo art. 108.4 establece que «la iniciativa legislativa ante el Congreso de los Diputados corresponde... a los ciudadanos, de acuerdo con el art. 87.3 de la Constitución y con la Ley Orgánica que lo desarrolle»).

Por otra parte, y según el artículo 127 del mencionado Dictamen, será la Mesa de la Cámara quien verifique si la iniciativa se ajusta a los requisitos legalmente establecidos. En nuestro ordenamiento no existe la menor posibilidad de que este futuro control de legalidad ejercido por la Cámara frente a las proposiciones de origen popular pueda dar lugar a un conflicto constitucional, en la acepción técnico-jurídica del concepto (art. 59.3 de la LOTC, a sensu contrario) ${ }^{9}$.

En fin, admitidas a trámite, las proposiciones de origen popular deben esperar luego a ser incluidas en el orden del día del Pleno, quien decidirá si las toma o no en consideración; espera que puede resultar larga ${ }^{10}$. Por lo

va a suceder: véase al efecto el Dictamen de la Comisión de Reglamento del Congreso en el BOCG/CD-H, núm. 33-II, de 17-VI-1981).

${ }^{8}$ Véanse en este sentido los arts. 126 y 127 del Dictamen de la Comisión de Reglamento del Congreso citado en la nota anterior.

9 Sobre tal eventualidad en Italia, véanse las sugerencias de Galeotti, op. cit., págs. 256257, n. 31.

Ahora bien: de aceptar - y no sería arriesgado hacerlo- que la iniciativa popular constituye una de las articulaciones en que se concreta el derecho reconocido en el artículo 23.1 de la Constitución, habría que entender que un uso incorrecto del control de legalidad por la Mesa del Congreso resultaría susceptible de recurso de amparo, tal como parece permitir el art. 42 de la LOTC. Al propósito no creo que se plantearan problemas insolubles de legitimación (art. 46.1.a de la LOTC).

${ }_{10}$ En relación con idéntico problema en Italia, véanse las reflexiones de E. Bettinelli, «Note sull'iniziativa legislativa popolare nell'ordinamento costituzionale italiano», en Il Politico, 1970, págs. 608-609. La cuestión está sufriendo entre nosotros una evolución significativa. En primer lugar, el Dictamen de la Comisión de Reglamento ordena la publicación de las proposiciones nada más ser admitidas a trámite (o sea, verificado positivamente el control de legalidad: art. 126.2), mientras que el Reglamento Provisional hace depender esa publicación de la toma en consideración por el Pleno; en segundo lugar, el Dictamen suprime el requisito del envío de las proposiciones a la Comisión correspondiente para que manifieste su criterio respecto a la toma en consideración; por último, el 
demás, a la sesión plenaria en que se debata la toma en consideración de estas proposiciones no tiene acceso ninguno de sus suscriptores en representación de los restantes y con vistas a defender el texto que se propone, lo que choca con la situación de los otros titulares de iniciativa legislativa. Nada se opone a que el Reglamento definitivo del Congreso corrija esta lamentable ausencia, pero no parece que lo vaya a hacer ${ }^{11}$.

F) Una vez formulada por los electores y tomada en consideración por el Congreso, la proposición recorre el resto del iter legislativo con absoluta independencia de sus suscriptores, ausentes en la totalidad de las fases del procedimiento. No tiene sentido plantear, como se hace en Italia ${ }^{12}$, el tema de la eventual retirada de esta clase de proposiciones, por la sencilla razón de que entre nosotros tal facultad se agota con el trámite de la toma en consideración, de manera que su alcance práctico resultaría muy limitado ${ }^{13}$. Mayor interés, en cambio, puede suscitar la cuestión de su caducidad a causa del término de la legislatura de modo natural o anticipadamente. Nada dice al respecto el Reglamento Provisional del Congreso. Por su parte, una Resolución de la Presidencia de la Cámara de 19-IV-1979 permite rehabilitar las proposiciones de iniciativa congresual. Sin embargo, el artículo 207 del texto del Dictamen de la Comisión de Reglamento prevé que, «disuelto el Congreso de los Diputados o expirado su mandato, quedarán caducados todos los asuntos pendientes de examen y resolución por la Cámara, excepto aquellos de los que constitucionalmente tenga que conocer su Diputación Permanente» ${ }^{14}$. Pues

Dictamen dispone que, pasados treinta días sin que el Gobierno haga uso de la prerrogativa que le confiere el art. 134.6 de la Constitución, «la proposición de ley quedará en condiciones de ser incluida en el orden del día del Pleno para su toma en consideración» (el plazo corre desde que el Gobierno recibe de la Mesa la proposición admitida a trámite -art. 126.2 y 3-), en tanto que el Reglamento Provisional determina que, transcurridos quince días desde la recepción de la proposición por el Gobierno y por la Comisión correspondiente, se incluirá esa proposición «en el orden del día del próximo Pleno, salvo que el mismo Pleno acordare otra cosa» (arts. 92.4, 5 y 6 y 108.2).

1 Sobre la cuestión en Italia véase Bettinelli, ibid., págs. 612-614.

12 Véase, entre otros muchos, Cicconetti, «Il potere di ritiro nel procedimento di formazione delle leggi», en Riv. Trim. Dir. Pubb., 1965, págs. 409-410; Cuocolo, op. cit., pág. 646; Bettinelli, op. cit., págs. 618-619, etc.

is El art, 100.2 del Reglamento Provisional del Congreso, refiriéndose únicamente a las proposiciones de origen congresual, determina que podrán retirarse antes de que la Cámara las haya tomado en consideración. El art. 129 del texto del Dictamen de la Comisión de Reglamento, sin embargo, sin hacer distinción entre las diversas especies de proposiciones, además de prescribir que «la iniciativa de retirada de una proposición de ley por su proponente tendrá pleno efecto por sí sola, si se produce antes del acuerdo de la toma en consideración», añade que, «adoptado éste, la retirada sólo será efectiva si la acepta el Pleno de la Cámara». Pero semejante precepto parece haberse concebido esencialmente para las proposiciones debidas a la iniciativa congresual, sin tener en cuenta a las de otra procedencia (véase el Diario de Sesiones del Congreso de los Diputados, Com. Regl., núm. 30, sesión del 28-V-1981, págs. 1412-1414).

${ }^{14}$ Véase el Diario de Sesiones del Congreso de los Diputados, Com. Regl., núm. 32, sesión del 3-VI-1981, págs. 1526-1527.

Lo propio se dispone en la disposición adicional primera del Proyecto de Reglamento del Senado (Informe de la Ponencia: BOCG/S, Serie III, núm. 13, de 1-VI-1981). Sin embargo, en este texto se prevé también un sistema de rehabilitación; así, su art. 129 permite que:

1) «Dentro de los seis meses siguientes al inicio de cada legislatura, diez senadores 
bien: de aptobarse esta disposición -cuyo fundamento se encontraría en el artículo 89.1 de la Constitución ${ }^{15}$-, se daría un definitivo golpe de gracia al instituto de la iniciativa popular. Indudablemente, sería preciso exceptuar del ámbito de la caducidad aquellas proposiciones de origen popular que, durante la legislatura anterior, no hubieran sido objeto de examen por el Pleno en el trámite de toma en consideración ${ }^{16}$.

\section{La iniciativa legislativa de las Asambleas de las Comunidades Autónomas}

La iniciativa legislativa - entendida como facultad de depositar proposiciones de ley ante el Congreso de los Diputados-corresponde igualmente a las Asambleas de las Comunidades Autónomas (art. 87.2) ${ }^{17}$, pero también entonces se deja en libertad a la Cámara Baja de las Cortes Generales para que, por medio de su Reglamento, concrete los efectos reales y precise el alcance de esa concesión (art. 89.1; en seguida se verá de qué libertad se trata). Debe señalarse, no obstante, que tal iniciativa carece de los límites materiales que aprisionan a la de origen popular -exceptuando siempre los propios de los artículos 134.1 y 5 y 131 y también los derivados de las reservas de iniciativa atinentes a los proyectos de Estatutos de Autonomía y a su ulterior reforma (arts. 146, 147.3, 151.2 y 152.2)-, pudiendo versar, por tanto, sobre

podrán pedir que se tramiten los proyectos y proposiciones de ley que hubiesen sido aprobados por el Pleno o dictaminados por la Comisión correspondiente en el momento de finalizar la legislatura precedente.»

2) «En estos casos..., la Comisión legislativa competente podrá asumir como dictamen el texto anterior, introducir variaciones en el mismo o disponer la apertura del plazo de presentación de enmiendas y la continuación de los trámites ulteriores.»

3) «Respecto a los proyectos o proposiciones de ley pendientes de la elaboración del dictamen en el momento de finalizar la legislatura precedente, la Comisión competente podrá disponer, si lo estima oportuno, la aplicación del procedimiento previsto en los artículos 103 y siguientes (el ordinario) del presente Reglamento.»

is Véanse las reflexiones que sobre reserva de reglamento parlamentario en materia de procedimiento legislativo y sobre este punto en concreto efectúa Bassanini, Gli efetti della fine della legislatura sui procedimenti legislativi pendenti, Giuffrè, Milán, 1968, págs. $72 \mathrm{y}$ sigs.

${ }^{16}$ De modo similar se pronuncia Bassanini, op. cit., pág. 169 , n. 417.

${ }_{17} \mathrm{La}$ Constitución no exige que todas las Comunidades Autónomas posean una Asamblea: únicamente lo requiere de aquellas cuyos Estatutos sean aprobados por el procedimiento del art. 151. De otra parte, las Asambleas a que alude el art. 87.2 no tienen por qué ser siempre órganos legislativos, pues cabe perfectamente la posibilidad de Comunidades carentes de potestad legislativa (excepto, otra vez, cuando su Estatuto se hubiera adoptado por la vía del art. 151), aunque nada impide que todas resulten provistas de ella; cfr. sobre estas cuestiones S. Muñoz Machado, Las potestades legislativas de las Comunidades Autónomas, Civitas, Madrid, 1979, págs. 24 y sigs.; L. Vandelli, L'ordinamento regionale spagnolo, Giuffrè, Milán, 1980, págs. 261 y sigs. y 303 y sigs., y E. Alvarez Conde, Las Comunidades Autónomas, Editora Nacional, Madrid, 1980, págs. 150 y sigs. y. 221-222 (supone este último autor que, si las Asambleas de las Comunidades Autónomas «poseen la iniciativa legislativa en el ámbito estatal, lógicamente dichas Asambleas tendrán carácter legislativo» -pág. 222-; pero esto equivale a confundir iniciativa legislativa y potestad legislativa, cosas completamente diferentes). 
los objetos descritos en el artículo 87.3 y sobre reforma constitucional. Consideremos con algún detenimiento estas cuestiones:

A) Reconocida constitucionalmente la facultad de iniciativa legislativa en el ámbito estatal de las Asambleas de las Comunidades Autónomas, la normativa reguladora de su ejercicio se encuentra en los Estatutos de Autonomía y preceptos complementarios de los mismos en lo relativo a los actos preparatorios de la formulación de las proposiciones de ley (art. 148.1.1. ${ }^{\mathrm{a}}$ ) y en el Reglamento del Congreso en lo relativo a su tramitación introductoria por las Cortes Generales (art. 89.1).

Los Estatutos vasco, catalán y gallego -únicos vigentes en el momento de redactar este trabajo- se limitan a mencionar la referida facultad de iniciativa en términos similares a como lo hace la Constitución. Por su parte, el Reglamento del Parlamento de Cataluña de 29 de julio de 1980 dispone que la elaboración de estas proposiciones se efectuará conforme al procedimiento legislativo ordinario, aunque la resolución final habrá de adoptarse por mayoría absoluta, y determina los modos de fijación del número y de designación de los diputados de la Cámara catalana encargados de la defensa de tales proposiciones en el Congreso (art. 133).

El artículo 108.3..$^{\circ}$ del texto del Dictamen de la Comisión de Reglamento del Congreso reconoce que la iniciativa legislativa corresponde a las Asambleas autonómicas «de acuerdo con la Constitución y sus respectivos Estatutos y Reglamentos», de manera que los requisitos contenidos en el artículo 124 de dicho texto (véase supra, 1.E) han de entenderse dirigidos a las proposiciones de origen congresual únicamente, pues las normas competentes en este punto son, correctamente interpretados los artículos 87.2, 89.1 y 148.1.1. ${ }^{\mathrm{a}}$ de la Constitución, el Estatuto de la Comunidad respectiva y, con base en él, el Reglamento de la Asamblea autónoma. El problema puede resultar meramente académico (así, por ejemplo, el aludido art. 124 del Dictamen contiene idénticos requisitos que los exigidos en el art. 104 del Reglamento del Parlamento de Cataluña), pero no es imposible que los reglamentos parlamentarios regionales requieran formalidades distintas a las demandadas por el del Congreso para la formulación de proposiciones de ley. $\mathrm{El}$ asunto presenta más interés del que superficialmente aparenta. En efecto, el control de legalidad previsto en el artículo 127 del Dictamen («las proposiciones de ley de las Comunidades Autónomas... serán examinadas por la Mesa del Congreso a efectos de verificar el cumplimiento de los requisitos legalmente establecidos») sólo cabe que tenga como parámetro la Constitución, el Estatuto de Autonomía respectivo y el Reglamento de la Asamblea regional (o norma a que, al propósito, se remita el Estatuto, en su caso), pero no el Reglamento del Congreso, siendo, desde luego, concebible, aunque no probable, que el parámetro venga constituido también por una ley de armonización (art. 150.3). Importa destacar que este control -igual que el que ha de operar sobre las proposiciones de origen popular y sobre los proyectos de Estatutos de Autonomía (arts. 136 y 137 del Dictamen) - es de carácter preventivo, vinculado (no libre) y de mera legitimidad formal ${ }^{18}$. En realidad, la Mesa de la Cámara, en el ejercicio

18 Véase sobre estas características, en términos generales, Galeotti, «Controlli costituzionali», en Enc. del Dir., t. X, Giuffrè, Milán, 1962, págs. 319 y sigs. 
de su función registral, está obligada a hacer lo mismo con las demás clases de proposiciones y con los proyectos, en cumplimiento de las disposiciones legales, de los preceptos de su propio Reglamento y del artículo 88 de la Constitución. El problema radica aquí en dilucidar si, puesto que la competencia de la Mesa es de simple verificación, cabe que una eventual disconformidad de la Asamblea regional proponente sea sustanciada por la vía de los conflictos constitucionales ${ }^{19}$. Al respecto, deben hacerse estas distinciones:

a) La Mesa del Congreso otorga su conformidad a una proposición de origen regional adoptada con infracción de la normativa pertinente. Es claro que si tal proposición llegara a convertirse en ley sería susceptible de declaración de inconstitucionalidad (art. 28.1 LOTC), aunque tal declaración únicamente resulta instable mediante recurso directo (arts. 32 a 34 LOTC).

b) La Mesa del Congreso rechaza la propoșición por entender que no cumple «los requisitos legalmente establecidos». ¿Qué podría hacer entonces la Asamblea proponente? ¿Habria lugar a plantear un conflicto de competencia en los términos previstos en los artículos 60 y siguientes de la LOTC? Indudablemente, esta ley no ha tenido presente semejante eventualidad, como lo prueba el que, mientras las Asambleas de las Comunidades Autónomas se hallan legitimadas para interponer recursos de inconstitucionalidad (art. 32.2), el planteamiento de los conflictos, en cambio, corresponde únicamente a los «órganos colegiados ejecutivos» regionales (arts. 60 y 63), con lo que todo dependerá del tipo de vinculación entre éstos y aquéllas. Pero lo esencial ahora es considerar que una incorrecta declaración de ilegalidad de la proposición por parte de la Mesa del Congreso implica una vulneración constitucional. Dicho de otro modo: la competencia otorgada por el Reglamento del Congreso a esta Cámara sólo es válida si la verificación resulta correcta; en caso contrario, entrará en juego el artículo 63.1 LOTC y se podrá plantear el conflicto contra la resolución congresual.

B) Respecto al trámite de la toma en consideración, valen las observaciones ya efectuadas sobre el mismo tema en materia de proposiciones debidas a la iniciativa popular. Puede añadirse ahora que las diferencias entre los institutos del control de legalidad, previo a la admisión a trámite, y de la toma en consideración resultan evidentes. Mientras el primero se virtualiza en actos de mera comprobación, totalmente reglados, el segundo se concreta en actos absolutamente libres, no sometidos a parámetros normativos que impongan una resolución determinada.

Pero el trámite de la toma en consideración de las proposiciones regionales presenta una singularidad. $\mathrm{La}$ Constitución requiere que tales proposiciones sean defendidas ante el Congreso por una representación de la Asamblea proponente (art. 87.2), representación cuya misión se agota tras la resolución de la Cámara en orden a la toma en consideración o rechazo del texto presentado! La defensa se ejerce, pues, sólo en la fase introductoria del procedimiento legislativo; concretamente, durante el debate de la toma en consideración. Esto se deduce ya del propio artículo 87.2 de la Constitución, que establece la representación únicamente ante el Congreso (careciendo de sentido, por tan-

${ }^{19}$ Véase, para Italia, Galeotti, Contributo..., cit., loc. ult. cit. 
to, que la representación continuara en la fase constitutiva congresual y se interrumpiera en la senatorial), y se corrobora por el Reglamento del Parlamento de Cataluña (art. 133) y, más explícitamente, por el Dictamen de la Comisión de Reglamento (art. 127).

En punto a la eventual retirada de esta clase de proposiciones y a la caducidad de las mismas, nos remitimos a lo ya expuesto sobre las de iniciativa popular en la misma cuestión (véase supra, 1.F). Pero, finalizada la legislatura de la Asamblea proponente, ¿se mantienen sus proposiciones aún no tomadas en consideración? Parece lo más lógico que no decaigan automáticamente, a la espera de su confirmación o retirada por la nueva Asamblea.

C) Pero, sin duda, el problema más importante es el de los límites materiales de esta clase de iniciativa, que Santamaría Pastor quiere circunscribir a «la promoción de las normas estatales de articulación entre las competencias del Estado y de las Comunidades Autónomas que bayan de promulgarse en virtud de lo dispuesto en los artículos 149 y 150 de la Constitución» ${ }^{20}$. Entre otros argumentos, aduce Santamaría «una aplicación elemental del principio de especialidad o del límite del interés general en el ejercicio de las competencias autonómicas», principio - prosigue- «ampliamente desarrollado en la doctrina italiana... y aplicable a España en virtud de lo dispuesto en el artículo 137 de la Constitución, que condiciona la autonomía de municipios, provincias y Comunidades Autónomas a 'la gestión de sus respectivos intereses'... ${ }^{21}$.

Esta tesis carece, no obstante, de todo fundamento. En efecto, ya la ubicación sistemática del artículo 87.2 permite afirmar, en principio, la inexistencia de tales límites materiales, por contraste con cuanto expresamente se dice en el artículo 87.3 respecto a las proposiciones de origen popular; afirmación y contraste que se ratifican en el artículo 166, el cual, además de otorgar iniciativa legislativa a las Asambleas de las Comunidades Autónomas en materia de reforma constitucional, excluye de este campo a la iniciativa popular. Así, los únicos límites expresos a la iniciativa regional son los derivados de las reservas de iniciativa dispuestas por los artículos 134.1 y $5,131,146$, $147.3,151.2$ y 152.2 , límites que comparten las diversas clases de proposiciones. Todo ello atestigua que se ha querido otorgar a los entes territoriales autónomos un medio de participación en la determinación de la orientación política general, lo que cuadra con el principio democrático que la propia Constitución proclama y la correlativa exigencia de una pluralidad de centros generadores de iniciativa legislativa. Esta voluntad del constituyente se refleja también en las facultades que poseen las Asambleas comunitarias de «solicitar del Gobierno la adopción de un proyecto de ley» (art. 87.2) y de designar cierto número de senadores (art. 69.5) ${ }^{22}$.

De otra parte, no es correcta, en este caso, la invocación del artículo 137

${ }^{20}$ J. A. Santamaría Pastor, en F. Garrido Falla y otros, op. cit., pág. 888. E1 subrayado es del autor citado.

${ }_{21}$ Ibid., loc. cit.

22 Véanse al respecto las observaciones que formula Martines sobre las regiones italianas en su «Studio sull'autonomia politica delle Regioni in Italia», en Riv. Trim. Dir. Pubb., núm. 8, 1956, págs. 103-104, 125 et passim. 
como soporte del criterio de especialidad y límite de la actividad de las Asambleas autonómicas, 'pues la facultad de iniciativa en el ámbito estatal que la Constitución reconoce a tales Asambleas no se conecta con el concepto de autonomía, que siempre implica una relación de contraposición ${ }^{23}$, sino con el principio democrático que preside la forma de Estado y que implica participación. En fin, el ejemplo italiano no es extrapolable como base de interpretación en este punto ${ }^{24}$.

A pesar de todo, este tipo de iniciativa previsiblemente se ejercerá en la dirección que Santamaría quiere marcarle de manera forzosa; mas, si alguna vez sucediera otra cosa, si dicha iniciativa se ejerciera sobre una materia de interés general, resultaría jurídicamente inatacable ${ }^{25}$.

D) Ya finalmente, la iniciativa legislativa regional queda sujeta, en cuanto a su tramitación e igual que las demás clases de proposiciones, al requisito de la conformidad gubernamental cuando implique «aumento de los créditos o disminución de los ingresos presupuestarios» (art. 134.6 de la Constitución). El texto del Dictamen de la Comisión de Reglamento del Congreso dispone que, admitida a trámite, tras el oportuno control de legalidad, la proposición regional, la Mesa ordenará su publicación y «su remisión al Gobierno para que manifieste... su conformidad o no a la tramitación si implicara aumento de

${ }^{23}$ Véase Martines, ibíd., pág. 102.

${ }^{24}$ El art. 121 de la Constitución italiana dice que el Consejo Regional «podrá hacer proposiciones de ley a las Cámaras», sin mencionar límites de ningún género. De idéntico modo se expresa el art. 22 de la Ley de 10-II-1953, núm. 62, sobre constitución y funcionamiento de los órganos de las regiones de estatuto ordinario. Ahora bien: ocurre que cuatro de las cinco regiones de estatuto especial —adoptado, como es sabido, mediante ley constitucional - restringen, de diferente guisa, la facultad otorgada por la Constitución a aquellas materias de interés regional, lo que, unido a la ubicación del precepto constitucional de referencia (situado en el título dedicado a las regiones y no en el consagrado a la elaboración de las leyes estatales, como sucede en la Constitución española), hace opinar a la mayoría de los autores en el sentido de extender la restricción a la totalidad de las regiones (cfr. Cuocolo, op. cit., págs. 633-635; en contra de la tesis dominante, Martines; cit., pág. 125). Aun esta doctrina, sin embargo, reconoce la dificultad de precisar, tanto en sede científica como jurisprudencial, qué ha de entenderse por materias de interés regional y recomienda flexibilidad al propósito, apoyándose en la no identificación por los estatutos especiales entre materias objeto de la competencia legislativa regional y materias de interés regional (cfr. Spagna-Musso, L'iniziativa nella formazione delle leggi italiane, I, Jovene, Nápoles, 1958, págs. 96-97, y Cuocolo, op. cit., pág. 635).

${ }^{25}$ No podría, pues, la Mesa del Congreso rechazar su admisión a trámite por la vía del instituto del control de legalidad previsto en el art. 127 del texto del Dictamen de la Comisión de Reglamento.

Importa poner de relieve igualmente la incorrección en que, a mi juicio, se hallarían los Estatutos y/o los reglamentos parlamentarios regionales si pretendieran testringir la esfera material de la facultad otorgada por el art. 87.2 de la Constitución. También incurriría en inconstitucionalidad una ley de armonización que quisiera lo propio; no, en cambio, una ley de armonización que, en pura hipótesis, ordenara el sistema de actos preparatorios de la formulación de las proposiciones en cuestión.

Por último, y dada su conexión con el tema que nos ocupa, debe reseñarse la incorrección misma del art. 32.2 de la LOTC, que restringe el campo material del recurso de inconstitucionalidad cuando éste se interponga por las Comunidades Autónomas a aquellas «leyes, disposiciones o actos con fuerza de ley del Estado que puedan afectar a su propio ámbito de autonomías, en contraposición a la indiscriminación objetual con que este procedimiento aparece al respecto contemplado en la Constitución:-arts. 161.1.a y 162.1.a. 
los créditos o disminución de los ingresos presupuestarios» (art. 126.2). «Transcurridos treinta días sin que el Gobierno hubiera negado expresamente su conformidad a la tramitación, la proposición de ley quedará en condiciones de ser incluida en el orden del día del Pleno para su toma en consideración» (art. 126.3). La normativa futura resulta muy parecida a la que contempla el vigente Reglamento Provisional (art. 108.2), aunque, de acuerdo con el nuevo artículo 134.6 constitucional, más severa respecto a la cuantía del aumento de gastos. Pero lo que interesa es lo que se puede hacer en caso de conflicto, o sea, cuando se produzca una discrepancia entre el Gobierno (que entiende que hay aumento de los créditos o minoración de los ingresos presupuestarios en la proposición regional) y la Asamblea proponente (que estima constitucionalmente correcta la proposición por ella formulada). Vaya por delante que, tal como se deduce del Reglamento Provisional y del Dictamen, ambos en adecuada sintonía con el precepto constitucional de referencia, el Pleno del Congreso no se halla autorizado a cumplir el trámite de la toma en consideración si el Gobierno niega su conformidad a la proposición por los motivos aducidos. No le queda entonces a la Asamblea autonómica proponente otro remedio que instar al «órgano ejecutivo superior» del ente territorial al que pertenece a emprender el procedimiento regulado en los artículos $63 \mathrm{y}$ siguientes de la LOTC, procedimiento que estimo aplicable al propósito, aunque la LOTC no parezca haber parado mientes en ello. En efecto, el artículo 63.1 de la citada Ley establece que, «cuando el órgano ejecutivo superior de una Comunidad Autónoma considerase que una... resolución o acto emanado de la autoridad... del Estado no respeta el orden de competencias establecido en la Constitución, ... y siempre que afecte a su propio ámbito, requerirá... a éste para que sea(n)... anulados la resolución o el acto en cuestión». De no prosperar ese requerimiento, «podrá plantear el conflicto ante el Tribunal Constitucional» (art. 63.5). Ciertamente, la solución que se defiende se muestra un tanto forzada, habida cuenta de su aparente desconocimiento por la LOTC, pero, al menos a título de hipótesis, vale la pena detenerse en su consideración, pues el tema de la iniciativa financiera de las Comunidades Autónomas encierra potencialmente tensiones de gran envergadura.

\section{INICIATIVAS PARLAMENTARIA Y GUBERNAMENTAL}

\section{La iniciativa legislativa parlamentaria}

Por lo que atañe a la iniciativa parlamentaria en general, según es contemplada en nuestro ordenamiento, debemos comenzar diciendo que se trata de una iniciativa que pertenece a cada una de las Cámaras y no a sus componentes individualmente considerados: «La iniciativa legislativa —declara el artículo 87.1 - corresponde... al Congreso y al Senado, de acuerdo con la Constitución y los Reglamentos de las Cámaras.» Así, ni los parlamentarios ni los Grupos en que se integran poseen más que una facultad para promover la iniciativa de la Asamblea de la que forman parte; de ahí el carácter de acto 
constitutivo que reviste la toma en consideración ${ }^{26}$. De otro lado, la iniciativa senatorial — que se traduce en la presentación de proposiciones de ley ante la Mesa del Congreso- se virtualiza jurídicamente como tal únicamente tras el acuerdo adoptado al propósito por la Alta Cámara, sin que el trámite de la toma en consideración por el Congreso resulte, de persistir ${ }^{27}$, otra cosa que un simple requisito de procedibilidad, un puro acto de control sucesivo que no afecta al momento del nacimiento de la iniciativa.

Pues bien: esa facultad de promover la iniciativa compete, reglamentariamente, a los miembros de las Cámaras y a los Grupos parlamentarios. Sin embargo, tampoco en el primer caso estamos ante una facultad individual $y$, además, existe desigualdad entre ambas clases de promoción, primando la de los Grupos parlamentarios ${ }^{28}$.

${ }^{26}$ Cfr. Cuocolo, op. cit., pág. 640, y Spagna-Musso, op. cit., pág. 72, con referencia a la situación italiana durante el período estatutario.

${ }^{27} \mathrm{El}$ art. 89.2.C determina que las proposiciones de ley tomadas en consideración por el Senado han de remitirse al Congreso para su tramitación en esta Cámara como tales próposiciones. Esto las convierte en proposiciones beterónomas, imposibilitadas de abrir por sí mismas la fase constitutiva del procedimiento legislativo.

De resultas de tan absurdo precepto, las relaciones entre ambas Cámaras han conocido momentos de tensión, al pretender, sin éxito, los senadores que sus proposiciones fueran siempre tomadas en consideración por el Congreso. Jurídicamente, sin embargo, no tenían razón si nos atenemos a los apartados 1 y 2 del art. 89. Ahora bien: el art. 125 del Dictamen de la Comisión de Reglamento del Congreso, recogiendo la reivindicación senatorial, libera a las proposiciones en cuestión del aludido trámite, otorgándoles, por tanto, acceso directo a la fase constitutiva. De acuerdo con el art. 89, la previsión del Dictamen resulta tan correcta como otra de signo contrario. Si prospera finalmente, la «guerra de las Cámaras» habrá concluido.

${ }^{28}$ A tenor del art. 92.2 del Reglamento Provisional del Congreso, «los diputados podrán presentar proposiciones de ley, que deberán llevar la firma, a efectos de conocimiento, del portavoz del Grupo a que pertenezcan y contar con el apoyo, mediante firma, de otros catorce miembros de la Cámata». En cambio, el art. 126.1 del texto del Dictamen de la Comisión de Reglamento suprime el requisito de la firma del portavoz del Grupo parlamentario. ¿Cuál es la razón de la coexistencia de las dos clases de promoción de la iniciativa si todos los diputados han de encuadrarse obligatoriamente en un Grupo parlamentario? Sencillamente, la no necesaria coincidencia entre componentes de un Grupo y miembros de una sola formación política, situación (reglamentariamente prevista en el Congreso, pero igualmente posible en el Senado) que excede del simple supuesto atinente al Grupo Mixto y en la que influye además el número mínimo de diputados requerido para la constitución de los grupos. Ello no obstante, circunscribiéndonos estrictamente a los textos normativos (que varían en su mayor o menor severidad al respecto: primitivo art. 20.1 del Reglamento Provisional del Congreso, el mismo precepto en su redacción actual, más tolerante, $\mathrm{y}$ art. 23 del Dictamen, más exigente), constatamos que siempre se privilegia la promoción de la iniciativa debida a los grupos, puesto que su composición numérica puede ser menor de quince diputados.

Por su parte, y de manera todavía más restrictiva, el Reglamento Provisional del Senado exige que las proposiciones vayan «suscritas por un Grupo parlamentario o veinticinco senadores, salvo en el supuesto de que entrañen aumento de gastos o minoración de ingresos para el Tesoro sobre los consignados en los Presupuestos Generales, en cuyo caso requetirán la firma de cincuenta senadores» (art. 97.1). Aun contando con que el último requisito ha sido suprimido en el texto del Proyecto de Reglamento del Senado informado por la Ponencia de la Comisión pertinente, sin duda al considerar lo dispuesto en el art. 134.6 de la Constitución, lo cierto es que se prima la iniciativa de los Grupos parlamentarios mucho más que en el Congreso, habida cuenta de que el número total de senadores resulta bastante menor que el de diputados y de que, mientras en el Congreso la relación entre el número mínimo de miembros con que ha de contar un Grupo 
De otra parte, si bien los únicos límites materiales de las proposiciones de origen parlamentario radican en las reservas de iniciativa establecidas en los artículos 134.1 (Presupuestos del Estado), 131 (planificación económica), 146, 147.3, 151.2 y 152.2 (proyectos de Estatutos autonómicos y de reforma de los Estatutos vigentes) ${ }^{29}$, «toda proposición o enmienda que suponga aumento de los créditos o disminución de los ingresos presupuestarios requerirá la conformidad del Gobierno para su tramitación» (art. 134.6), en tanto que, «aprobados los Presupuestos Generales del Estado, el Gobierno podrá presentar proyectos de ley que impliquen aumento del gasto público o disminución de los ingresos correspondientes al mismo ejercicio presupuestario» (art. 134.5). Es decir:

A) La iniciativa consistente en la presentación del proyecto de Ley de Presupuestos compete en exclusiva al Gobierno, limitándose las Cámaras a su examen, enmienda y aprobación, según reza el artículo 134.1, el cual detalla significativamente la competencia parlamentaria enunciada con menor concreción por el artículo $66.2^{30}$.

B) Una vez aprobados los Presupuestos, el Gobierno puede presentar proyectos que entrañen aumento del gasto o minoración de los ingresos co-

parlamentario y el de diputados suscriptores de una proposición es de cinco a quince (con el primitivo art. 20.1 del Reglamento Provisional era de 15/15, salvo para las formaciones políticas del nacionalismo periférico, y lo propio ocurte con el Dictamen), en el Senado es de diez a veinticinco (o incluso de diez a cincuenta).

${ }^{29}$ Sin embargo, la iniciativa para tramitar los decretos-leyes como proyectos de ley corresponde sólo al Congreso, según parece la interpretación más correcta del art. 86.2 y 3 (y así lo confirma el art. 151.4 y 5 del Dictamen, que atribuye la promoción de la iniciativa a los Grupos parlamentarios).

${ }^{30} \mathrm{La}$ facultad de enmienda durante el debate presupuestario no se halla cortapisada por la exigencia de conformidad gubernamental requerida por el art. 134.6, precepto que entra en juego sólo después de aprobados los Presupuestos (cfr. E. Recoder de Casso, «El debate parlamentario de los Presupuestos Generales del Estado», en Revista del Departamento de Derecho Político, UNED, núm. 4, 1979, págs. 118-119; E. González García, «La Ley del Presupuesto en la Constitución española de 1978», en Presupuesto y Gasto Público, núm. 3, pág. 136, y F. Escribano López, Presupuesto del Estado y Constitución, IEF, Madrid, 1981, págs. 296 y sigs.; en contra, véanse A. Rodríguez Bereijo, «La Ley de Presupuestos en la Constitución española de 1978\%, en la obra colectiva La Hacienda Pública en la Constitución española, IEF, Madrid, 1979, págs. 237-239, y P. J. Pétez Jiménez, «Las limitaciones a la iniciativa legislativa financiera en la Constitución española», en Revista de Derecho Político, UNED, núm. 9, 1981, págs. 135 y sígs.). Sin embargo, los Reglamentos Provisionales de las Cortes determinan que, cuando se trate de enmiendas que impliquen aumento. de crédito en algún concepto presupuestario, deberán proponer una baja de igual cuantía en otro concepto de la misma sección, mientras que cuando se trate de enmiendas que entrañen minoración de ingresos, requerirán la conformidad gubernamental (arts. 107.2 y 3 y 108.2 y 3 del Reglamento Provisional del Congreso y 102.2 y 3 y 103.2 y 3 del Reglamento Provisional del Senado). Lo mismo se dispone en el art. 133.3 y 4 del Dictamen de la Comisión de Reglamento del Congreso y, en punto a aumento del gasto, en el art. 147 del Proyecto de Reglamento del Senado informado por la Ponencia. Ahora bien: la exigencia reglamentaria de la conformidad gubernamental para la admisión a trámite de las enmiendas que comporten minoración de ingresos me parece, respecto al procedimiento presupuestario, contraria al artículo 134.1 de la Constitución, precepto que en su expresividad impide la denegación liminar de la facultad que otorga (a favor de la autolimitación por vía reglamentaria, en cambio, Pérez Jiménez, ibíd., pág. 138.). 
rrespondientes al mismo ejercicio presupuestario, proyectos que las Cortes siempre pueden enmendar a la baja libremente (art. 134.6, a sensu contrario) o, desde luego, rechazar ${ }^{31}$.

C) Ahora bien: para que se pueda admitir a trámite una proposición de ley o una enmienda a un proyecto de ley que supongan los referidos aumento y minoración con relación a los Presupuestos vigentes se requerirá la conformidad gubernamental ${ }^{32}$.

En fin, ni el Gobierno, en la redacción del proyecto presupuestario, ni las Cámaras, mediante enmiendas introducidas a lo largo de los debates de la Ley de Presupuestos, están habilitados para crear tributos; únicamente cabe que modifiquen los ya existentes cuando así lo autorice una ley sustantiva previa ${ }^{33}$. Tampoco les es posible, al Gobierno y a las Cortes, alterar el importe de los créditos destinados a la amortización e intereses de la Deuda Pública legalmentè previstos, automáticamente incluidos en el estado de gastos de los Presupuestos, salvo, naturalmente, que se hubiera modificado la ley de emisión (art. 135.2).

Ya se ha aludido al tema de la retirada y al de la caducidad de las proposiciones (véase supra, I.1.F). Respecto al primero, en nuestro ordenamiento sólo existe una facultad de retirada de la promoción de la iniciativa, toda vez que dicha facultad opera únicamente antes de que se haya procedido a la toma en consideración; ello encaja con la atribución constitucional de la iniciativa a las Cámaras y no a sus miembros y con el carácter constitutivo de la iniciativa que reviste el trámite de la toma en consideración ${ }^{34}$. Mas la cuestión de la retirada de las proposiciones reviste mayor complejidad en él Senado, a

${ }^{31}$ Véase, en el mismo sentido, Pérez Jiménez, ibíd., págs. 144-145.

${ }^{32}$ «Tiene especial relevancia -escribe Cazorla- la matización de que tanto el aumento de los créditos como la disminución de los ingresos lo han de ser respecto a los créditos e ingresos presupuestarios; es decir, los fijados en los Presupuestos vigentes al tiempo del examen de la enmienda o proposición de que se trate...» Con ello, añade más adelante, «se ha ampliado notablemente el ámbito de la iniciativa parlamentaria en este terreno y de alguna forma se ha empequeñecido la exigencia de la conformidad gubernamental para las enmiendas y proposiciones de ley que entrañen aumento de gastos o disminución de los ingresos. En efecto, en el caso de que unas y otras no afecten al presupuesto en vigor, podrán tramitarse... sin necesidad de conformidad del Gobierno, lo cual le puede plantear la papeleta de tener que afrontar en el ejercicio económico siguiente nuevos gastos o minoración de ingresos, que pueden incidir de alguna manera en su plan de gobierno para tal período» (L. M. Cazorla Prieto, en F. Garrido Falla y otros, op. cit., págs, 14411442; véase igualmente Pérez Jiménez, op. cit., pág. 144). Sobre la repercusión que la problemática delimitación del contenido de los Presupuestos, tal como es definido en el art. 134.2, produce en las limitaciones a la iniciativa parlamentaria del art. 134.6, véanse las interesantes consideraciones de Pérez Jiménez, ibíd., págs. 145-147. Véase también este mismo autor para el examen detallado de los problemas procedimentales que suscita la exigencia de la conformidad gubernamental (ibíd., págs. 128-129 y 150-158).

${ }_{33}$ Entendiendo por tal «cualquier ley ('propia' del impuesto o modificadora de ésta) que, exceptuando la de Presupuestos, regule elementos concretos de la relación tributarias, según se expresa en la sentencia del Tribunal Constitucional (Pleno/RI, núm. 38) de 20-VII-1981 (BOE de 13-VIII-1981).

${ }^{34}$ De ahí también que, como ya se dijo (supra, nota 13), el art. 129 del texto del Dictamen de la Comisión de Reglamento del Congreso disponga que, tomada en consideración por la Cámara una proposición, sólo podrá retirarse si así lo acepta el Pleno. 
causa de la posición subordinada de esta Așamblea en el procedimiento legislativo de las Cortes Generales y, en concreto, del carácter heterónomo de la iniciativa senatorial. En efecto, el vigente Reglamento Provisional de la Cámara Alta no menciona siquiera la eventualidad de referencia, a pesar de lo cual no cabe duda de que quienes han promovido la iniciativa de la Cámara pueden, antes de que ésta la haga suya, retirar el texto presentado. Sin embargo, sucede que el iter que ese texto debe recorrer es de mucha mayor longitud que en el Congreso ${ }^{35}$, pues, de acuerdo con las «Normas sobre tramitación de las proposiciones de ley» dictadas por la Presidencia de la Asamblea ${ }^{36}$, una vez formulada la proposición ${ }^{37}$, el presidente, de acuerdo con la Mesa y oída la Junta de Pórtavoces, decidirá sobre su inclusión «en el orden del día del Pleno de la Cámara, a efectos de que ésta se pronuncie sobre si procede o no su envío a la correspondiente Comisión»; si el Pleno no rechaza la proposición, ésta se traslada a la Comisión competente y se publica; a continuación, se abre el plazo de presentación de enmiendas, se designa una Ponencia encargada de elaborar el correspondiente Informe, se celebran los debates en la Comisión y ésta emite su Dictamen; por último, «el texto que, a la vista del dictamen de la Comisión, tome en consideración el Pleno del Senado, será enviado, a través de la Presidencia de éste, a la del Congreso de los Diputados para su tramitación ulterior». ¿Cuál es, entonces, el momento en que cabe ejercer la facultad de retirada? Lógicamente, aquel anterior a la toma en consideración definitiva por la Cámara del texto propuesto. Así lo dispone el Proyecto de Reglamento del Senado, el cual, siguiendo el modelo actual, distingue tres fases en la tramitación de la iniciativa: admisión preliminar del tẹto por la Mesa (control de legitimidad formal, destinado a verificar la conformidad de la proposición al Reglamento), admisión a trámite (cuando el Pleno se pronuncia acerca del envío de la proposición a la Comisión pertinente o su rechazo) y toma en consideración (cuando la Cámara da su conformidad final a un texto procedente de la misma y decide su remisión al Congreso «para su trámite en éste como tal proposición») ${ }^{38}$. Sin duda, todo ello resulta de un barroquismo enloquecedor.

Respecto al tema de la caducidad de las proposiciones al término de la legislatura, el problema principal radica en la suerte que han de correr en el Congreso las de origen senatorial en los casos de disolución únicamente de la Cámara Baja (ex art. $115.1 \mathrm{C}$ ). Al propósito, debe tenerse presente:

A) Que la competencia para decidir en esta cuestión corresponde al Reglamento del Congreso (art. 89.1 C) ${ }^{39}$.

B) Que, ello no obstante, sería de lamentar que dicho Reglamento procediera a una aplicación brutal y procesalmente indiscriminada del principio

${ }^{35}$ Sobre la situación en esta otra Cámara véase supra, nota 10.

${ }^{36}$ Véase el $B O C G / S$, Serie I, núm. 14, de 6-VII-1979.

${ }^{37}$ Véase supra, nota 28.

${ }^{38}$ Cfr. los arts. 36.1.c y 107 y 108 del Proyecto de Reglamento del Senado.

${ }^{39}$ Lo mismo sucede con el Reglamento del Senado (también art. 89.1.C); tanto en los casos de disolución únicamente del Congreso como de finalización de la legislatura de las dos Cámaras, compete al Reglamento de la Alta determinar la suerte de los textos recibidos de la Cámata Baja (véase supra, nota 14). 
de representatividad de las Asambleas ${ }^{40}$, sin establecer métodos de rehabilitación ${ }^{41}$.

C) Que, si en el Reglamento definitivo del Congreso se arbitraran dichos métodos, habría que distinguir no sólo entre proposiciones y proyectos, sino entre las diversas clases de proposiciones, graduando la rehabilitación de éstas en atención a su diferente origen ${ }^{42}$.

\section{La iniciativa legislativa gubernamental}

La iniciativa legislativa del Gobierno (art. $87.1 \mathrm{C}$ : se le cita en primer lugar) se traduce en el envío de proyectos de ley al Congreso. Tales proyectos - dice, en efecto, el artículo 88- «serán aprobados en Consejo de Ministros, que los someterá al Congreso, acompañados de una exposición de motivos y de los antecedentes necesarios para pronunciarse sobre ellos».

Pues bien: al margen de la cuestión de si «Gobierno» y «Consejo de Ministros» resultan hoy expresiones sinónimas o no ${ }^{43}$, lo cierto es que la iniciativa legislativa gubernamental se virtualiza mediante la decisión de un órgano colegiado - el Consejo de Ministros- cuyos miembros, situados formalmente en pie de igualdad (en el.sentido de no hallarse vinculados por relaciones de jerarquía), adoptan el acuerdo al propósito por mayoría, sin que el presidente del Gobierno pueda, jurídicamente, imponer su criterio de manera directa ${ }^{44}$.

De otra parte, y dado que los Reglamentos parlamentarios otorgan al Gobierno la facultad de retirar sus proyectos antes de que sobre los mismos hubiera recaído el acuerdo definitivo de la Cámara en que se encontraran ${ }^{45}$, cabe

40 Sobre el principio de representatividad de las Asambleas parlamentarias en relación çon el tema de los trabajos pendientes, véase Bassanini, op. cit., págs. 87 y sigs.

${ }^{41}$ Véase, sobre el estado actual y las expectativas de futuro de la cuestión de la rehabilitación, supra, I.1.F.

${ }^{42}$ Así, no sólo habría que excluir de la caducidad a las proposiciones de origen popular no sometidas en la legislatura anterior al trámite de la toma en consideración y permitir alguna forma de rehabilitación de las de origen regional (tanto de las que no hubieran accedido al mencionado trámite como las que se encontraran en trámites más avanzados) $\mathrm{e}$ incluso de las de procedencia congresual (respecto de las cuales, sin embargo, resultaría admisible una mayor severidad), sino que sería preciso permitir a la Cámara Alta rehabilitar sus proposiciones sea cual fuere el estadio en que se encontraran en la Baja durante la legislatura anterior: al fin y al cabo, el nuevo Congreso siempre podría modificar a su antojo, durante el debate plenario, el texto rehabilitado, y además, en el supuesto de que el Senado, no obstante tales modificaciones, insistiera, mediante enmiendas formuladas en la segunda mitad de la fase constitutiva del procedimiento legislativo, en la redacción primitiva, ahí están las reglas de resolución de conflictos del art. 90.C, extremadamente favorables al Congreso.

${ }^{43}$ Véase una opinión negativa en I. de Otto, «La posición constitucional del Gobierno de la nación», en Bastida, Punset y De Otto, Lecciones de Derecho constitucional. Organos constitucionales, I, Guiastur, Oviedo, 1980, págs. 341-343.

${ }_{44}$ Aunque referido al ordenamiento constitucional franquista, véase un análisis del priticipio de colegialidad en relación a la forma de trabajo del Consejo de Ministros en P. de Miguel, «Reuniones y acuerdos del Consejo de Ministros», RAP, núm. 83, 1977, págs. 241 y sigs.

${ }_{45}$ Arts. 100.1 del Reglamento del Congreso y 96 del Reglamento del Senado. Debe entenderse, a mi juicio, que, en caso de veto o enmiendas del Senado (art. 90) a un pro- 
preguntarse si resulta preceptiva la aprobación de dicha retirada por el Consejo de Ministros; y la respuesta tiene que ser positiva ${ }^{46}$. Mas, a continuación, ¿puede un Gobierno cesante o dimisionario presentar o retirar proyectos de ley? Desde luego, el Gobierno debe presentar el proyecto de Presupuestos Generales del Estado «al menos tres meses antes de la expiración de los del año anterior» (art. 134.3); y esa obligación resulta independiente de que se trate de un Gobierno «en funciones» (art. 101.2); por lo mismo, el Gobierno, sea cual fuere su situación, no puede retirar el proyecto presupuestario durante el último trimestre del año. Aquí, pues, la iniciativa se configura como un acto debido, de manera que la facultad de retirar - correlato de la iniciativa entendida como un acto libre ${ }^{47}$ - no existe. En los demás casos, y considerando el problema en términos estrictamente jurídicos, hay que estar al tenor literal de. los preceptos constitucionales y reglamentarios, los cuales no prohíben a los Gobiernos cesantes o dimisionarios la presentación (art. $88 \mathrm{C}$ ) o retirada de los proyectos de ley. Ahora bien: es obvio que la ratio del artículo $101.2 \mathrm{C}$ consiste tanto en evitar vacíos de poder cuanto en posibilitar la administración o gestión de los asuntos corrientes u ordinarios por el Gobierno «en funciones»; y está claro que las situaciones en que puede verse un Gobierno de estas características son muy variadas: no sólo resulta perfectamente concebible un Gobierno cesante de varios meses de duración ${ }^{48}$, sino también un Gobierno cesante o dimisionario enfrentado a casos de extraordinaria y urgente necesidad que le obliguen a emitir Decretos-leyes ${ }^{49}$ o a graves circunstancias que le aconsejen declarar o solicitar la declaración de alguno de los estados de crisis. Sin duda, la opción de presentar o no proyectos de ley depende de la duración de la interinidad gubernamental, así como la decisión de retirar se halla conectada a múltiples factores políticos; de ahí el silencio constitucional y reglamentario - la ausencia de prohibición expresa-, que equivale a remitir el problema bien a las costumbres constitucionales, bien a las reglas de corrección constitucional, pues, en efecto, este tipo de relaciones interorgánicas, que descansan sobre situaciones de gran fluidez, no son susceptibles de normación escrita ${ }^{50}$.

yecto aprobado por el Congreso, el Gobierno puede retirarlo antes del pronunciamiento final de esta Cámara, salvo, naturalmente, que su Reglamento dispusiera en el futuro otra cosa.

${ }_{45}$ Véase Cuocolo, op. cit., págs. 645-646.

${ }^{47}$ Cfr. Cicconetti, op. cit., págs. $285 \mathrm{y}$ sigs.

${ }^{48}$ «Si la causa (del cese del Gobierno) es dimisión, fallecimiento o celebración de elecciones generales -escribe Sánchez Agesta-, el Gobierno continúa en funciones durante un plazo máximo de dos meses, hasta que se consigue nombrar un nuevo Gobierno, de acuerdo con el art. 99. E incluso cabe suponer la hipótesis de que en ese plazo de dos meses no se constituya un nuevo Gobierno por no obtener ningún candidato la confianza del Congreso, en cuyo caso el Gobierno 'en funciones' continuará, una vez disueltas las Cámaras, hasta que el nuevo Congreso proceda a la formación de nuevo Gobierno. Como el plazo para la elección es entre treinta y sesenta días, dicho Gobierno en funciones puede sumar a los dos meses de gestión previa un total de dos meses y ochenta y cinco días. De hecho, más de cinco meses, sin contar la flexibilidad con que se computa la fecha inicial del plazo (desde la primera votación de investidura)» (El sistema político de la Constitución española de 1978, Editora Nacional, Madrid, 1980, pág. 226).

${ }^{49}$ Cfr. F. Santaolalla, en Garrido Falla y otros, op. cit., pág. 1018.

${ }^{5}$ Para las dificultades de juridificar los límites de la acción de los Gobiernos «en 
En cuanto a las exigencias de motivación y de aporte de la oportuna documentación ilustrativa, resulta difícil dilucidar en qué medida afectan a la validez «formal» de las leyes. Lo que sí es seguro es que la Mesa del Congreso no puede admitir a trámite los proyectos que las incumplan y que, en pura hipótesis, los eventuales conflictos entre el Gobierno y el Congreso --surgidos al socaire del ejercicio por la Mesa de esta Cámara del control de legalidad de los proyectos- han de solventarse conforme a lo previsto en los artículos 73 y siguientes de la LOTC. En fin, puesto que el Gobierno debe motivar sus proyectos, lo mismo tendría que hacer si los retirase ${ }^{51}$.

La iniciativa legislativa gubernamental sólo conce un límite material: el relativo a los proyectos de Estatutos de Autonomía y a la reforma de los Estatutos vigentes ${ }^{52}$. Por último, y aunque la Constitución no requiera el dictamen previo del Consejo de Estado ${ }^{53}$, tampoco lo prohíbe. El silencio constitucional ha permitido a la Ley Orgánica del Consejo de Estado de 22-IV-1980 ordenar la solicitud del parecer del alto órgano consultivo en una serie de supuestos ${ }^{54}$.

\section{Iniciativa legislativa y forma de gobierno}

Los proyectos en que se plasma la iniciativa gubernamental han de tener un tratamiento prioritario en su tramitación respecto a las proposiciones (art. $89.1 \mathrm{C}$ ). Esta prioridad se manifiesta, en primer lugar, en la facultad del Gobierno de activar la inclusión en el orden del día de los proyectos ${ }^{55}$, lo cual se produce sin perjuicio de su participación en la determinación del orden del día en general ${ }^{56}$ y de su facultad de instar la tramitación de un proyecto por el procedimiento de urgencia ${ }^{57}$, y, en segundo lugar, en la presunción de

funciones», véase Mazzoni, «Note sul 'Governo privo di fiducia' nell'ordinamento costituzionale italiano», en Riv. Trim. Dir. Pubb., 1980, págs. 177 y sigs.

${ }_{51}$ Cfr. Cicconetti, op. cit., págs. 391-392.

${ }_{52}$ Véase, no obstante, supra, nota 29.

${ }^{3}$ En cambio, sí lo requería el Informe de la Ponencia de la Comisión de Asuntos Constitucionales del Congreso para leyes orgánicas o de delegación legislativa (art. 81.1); mas la Comisión Mixta Congreso-Senado suprimió este requisito.

${ }_{54} \mathrm{Y}$ así, el art. 21 de dicha ley dispone que «el Consejo de Estado en Pleno deberá ser consultado en los... anteproyectos de leyes que hayan de dictarse en ejecución, cumplimiento o desarrollo de tratados, convenios o acuerdos internacionales èn los que España sea parte» y en los «anteproyectos de ley... que afecten a la organización, competencia o funcionamiento del Consejo de Estado». Por su parte, el art. 22 exige la consulta de la Comisión Permanente del Consejo en los «anteproyectos de Ley Orgánica de transferencias o delegación de competencias estatales a las Comunidades Autónomas».

${ }_{55} \mathrm{El}$ art. 54.3 del Reglamento del Congreso dispone que «se reservará la mitad de la semana para los proyectos de ley y comunicaciones del Gobierno cuando éste les dé carácter prioritario y así lo solicitè».

${ }_{56}$ Arts. 27 y 54 del Reglamento del Congreso.

${ }^{57} \mathrm{La}$ Constitución menciona dicho procedimiento en dos ocasiones: al aludir a la tramitación de los decretos-leyes como proyectos de ley (art. 86.3: véase supra, nota 29) y al regular la actividad legislativa del Senado (art. 90.3: «El plazo de dos meses de que el Senado dispone para vetar o enmendar el proyecto se reducirá al de veinte días naturales en los proyectos declarados urgentes por el Gobierno o por el Congreso de los Diputados»). Por su parte, el Reglamento del Congreso reconoce al Gobierno la iniciativa para proponerlo a la Cámara (art. 103.1). 
aceptación preliminar de los proyectos, pues sólo si la Comisión a la que se envían no aceptase entrar en su estudio habría de pronunciarse el Pleno ${ }^{58}$.

Por otro lado, nos encontramos con que, también respecto a las proposiciones, el Gobierno puede: primero, manifestar su criterio en relación a la toma en consideración de las mismas ${ }^{59}$; segundo, participar en la determinación de su inclusión en el orden del día ${ }^{60}$; y, tercero, instar su tramitación urgente ${ }^{61}$.

De todo lo dicho hasta el presente resulta, pues, que:

A) La iniciativa legislativa gubernamental padece menos límites materiales que las demás.

B) Existen importantísimas reservas de iniciativa a favor del Gobierno (en punto a Presupuestos Generales del Estado y planificación económica).

C) El Gobierno se halla facultado para oponerse eficazmente a la tramitación de las proposiciones contrarias a los Presupuestos vigentes.

D) El Gobierno, por último, no sólo actúa como impulsor en el Congreso de sus proyectos - privilegiados reglamentariamente--, sino que media en la suerte parlamentaria de las proposiciones de modo directo, esto es, sin necesidad de recurrir en principio al grupo o grupos parlamentarios que le sustentan.

Ocurre así que la iniciativa legislativa del Gobierno ocupa una posición de preeminencia sobre las otras clases de iniciativa. Es decir, no obstante la creación por el constituyente español de cinco centros generadores de iniciativa legislativa ${ }^{62}$, entre ellos no se da una relación de competencia, sino de integración, y más específicamente de integración de la iniciativa gubernamental, respecto de la cual operan secundariamente ${ }^{63}$. Tales integración y secundariedad de todas las iniciativas no gubernamentales resultan factibles gracias al trámite de la toma en consideración que se desarrolla en el Congreso, Cámara que, a causa de la relación fiduciaria que mantiene con el Gobierno, tamiza,

${ }^{58}$ Arts. 94 y 95 del Reglamento del Congreso. Así, mientras para las proposiciones existe un trámite de toma en consideración único, obligatorio y plenario (art. 92), para los proyectos, en cambio, se ha arbitrado un sistema de aceptación inicial, quebrantable en dos instancias.

${ }_{59}$ Tal dispone el art. 92.4 del Reglamento del Congreso. En el Dictamen de la Comisión de Reglamento se incluye dentro de las proposiciones susceptibles de opinión gubernamental también a las de origen popular y regional (arts. 126 y 127); no así a las senatoriales, que, adoptadas por su Cámara de procedencia, pasan, en el Congreso, directamente a Comisión (art. 125); mas, como quiera que el Proyecto de Reglamento del Senado suprime el trámite relativo a la manifestación del criterio del Gobierno (siguiendo en esto a la normativa vigente, citada supra, nota 36), nos vamos a topar con una incoherencia mayúscula: sobre todas las proposiciones podrá opinar el Gobierno, menos sobre las senatoriales.

${ }^{6}$ Arts. 27 y 54 del Reglamento del Congreso y 61.2 del Reglamento del Senado.

6 Arts. 103.1 del Reglamento del Congreso y 99.1 del Reglamento del Senado.

62 Sin contar la de adopción y reforma de los Estatutos de Autonomía. Esta vertebración pluralista del instituto de la iniciativa legislativa, que hay que conectar con el art. 1.1, alusivo a la forma democrática del Estado, sigue el ejemplo de la Constitución italiana -en la que, sin embargo, los titulares de la iniciativa son aún más numerosos, articulándose en un sistema de titularidad difusa, abierta (susceptible de ampliación) e integradora: cfr. Spagna-Musso, op. cit., págs. 23-24- y se aparta tanto del modelo tradicional cuanto del establecido en Francia y Alemania (véase Lucifredi, op. cit., págs. 23 y sigs. y 31 y sigs., y Cuocolo, op. cit., pág. 622).

${ }_{63}$ Cfr. Spagna-Musso, ibíd., pág. 202. 
mediante el referido trámite, no sólo las proposiciones ajenàs, sino también las propias. Todo esto encaja dentro de la forma de gobierno parlamentaria, en la que el Gabinete actúa de impulsor del trabajo legislativo. Veamos - para finalizar el presente trabajo- estas cuestiones con algún detenimiento.

A) El Gobierno goza de la confianza del Congreso con base en el programa de su presidente ${ }^{64}$, programa que ha de traducirse esencialmente en el envío a la Cámara de proyectos de ley ${ }^{65}$.

B) Dichos proyectos son susceptibles de contemplarse al mismo tiempo como manifestación de la función gubernamental de dirección de la política (art. 97) y como expresión de la programación gubernamental de la actividad legislativa.

En efecto, de una parte, la dirección de la política que la Constitución encomienda al Gobierno consiste en el conjunto de actos preparatorios (opciones y decisiones) del ejercicio de la potestad reglamentaria ${ }^{66}$ y de la facultad de iniciativa legislativa. De otra, el ejercicio de la facultad de iniciativa supone una predeterminación objetual —luego amparada reglamentariamentedel trabajo parlamentario.

C) La preeminencia gubernamental en la fase de iniciativa encuentra su

${ }^{64} \mathrm{Al}$ programa se refieren los arts. 99.2 y 112.2. No lo menciona, en cambio, el artículo 113 , pero en la práctica habida hasta el presente el candidato incluido en la moción de censura expuso también su programa (véase M. Gonzalo, «Crónica parlamentaria», en Revista del Departamento de Derecho Político, UNED, núm. 7, 1980, págs. 197 y sigs.); recogiendo esta experiencia, el Dictamen de la Comisión de Reglamento del Congreso permite al candidato en cuestión «exponer el programa político del Gobierno que pretende formar» (art. 177.1).

${ }_{65}$ Para la debida comprensión de la relación existente entre el programa y el ejercicio de la iniciativa legislativa conviene tener presentes estos extremos:

1. Quien recibe la confianza del Congreso es el candidato a la Presidencia del Gobierno (arts. 99.3 y 114.2) o el Gobierno mismo (en el caso del planteamiento exitoso por el presidente de la cuestión de confianza: arts. $112 \mathrm{y}$, a sensu contrario, 114.1). Sin embargo, en todos estos supuestos el programa es un documento de carácter unipersonal; también en el del art. 112 (véase I. de Otto, op. cit., págs. 348 y sigs.).

2. Quien designa y releva a los miembros del Gobierno es su presidente, que lo hace libremente (art. 100). Los miembros del Gobierno, individualmente considerados, sólo responden políticamente ante el presidente, no ante el Congreso (arts. 101.1, 108 y 114) (véanse De Otto, op. cit., págs. 362-367, y R. Punset, «Forma de gobierno del Estado y forma de gobierno tegional. Apuntes para un estudion, en Revista de la Facultad de Derecho de la Universidad Complutense, núm. 4 monográfico, 1981, pág. 86).

3. Si bien los proyectos en que se concreta el programa presidencial han de ser aprobados en Consejo de Ministros (órgano colegiado cuyos acuerdos se adoptan mayoritariamente, como sabemos), lo cierto es que tanto la designación y el cese de los componentes del Gobierno, libremente decididos por su presidente, cuanto el protagonismo de éste en los procedimientos parlamentarios de responsabilidad política y en el ejercicio del derecho de disolución, circunstancias complementarias de la función presidencial de dirección y coordinación (art. 98.2), hacen problemática la independencia de los ministros de los Gobiernos monocolores.

66 El art. 97 dice que el Gobierno «ejerce la función ejecutiva y la potestad reglamentaria de acuerdo con la Constitución y las leyes». Pues bien: aparte de que habría que dilucidar si «función ejecutiva» y «potestad reglamentaria» no vienen a ser, básicamente, la misma cosa (o a lo sumo ésta traducción de aquélla en el plano de la creación jurídica secundaria), la potestad reglamentaria se desarrolla con un margen de libertad en el tiempo (sin perjuicio de la doctrina del complemento indispensable en el ámbito de las relaciones entre ley y reglamento) capaz de configurarla como una manifestación de dirección política. 
justificación, obviamente, en la función directiva del Gobierno, la cual sólo adquiere virtualidad gracias a la confianza de la Cámara, confianza, a su vez, presumida por el Reglamento del Congreso en el tratamiento preliminar de los proyectos. En este contexto, las proposiciones de origen parlamentario desempeñan un papel bien de estímulo, bien de integración, o sea, desempeñan, de acuerdo con la lógica del sistema, un papel secundario ${ }^{67}$. ¿Cómo cohonestar la titularidad de la potestad legislativa de las Cortes (art. 66.2) con la preeminencia de la iniciativa del Gobierno? Pues, sencillamente, teniendo presente, primero, que iniciativa legislativa y potestad legislativa son dos cosas diferentes, como ya vimos en páginas anteriores (cfr. supra, I.1.D), y, segundo, que iniciativa legislativa y dirección política guardan entre sí una relación de medio a fin, por lo que la preeminencia gubernamental en este ámbito se corresponde con la necesidad de instrumentalizar la aplicación del artículo 97, que asigna al Gobierno la dirección de la política.

D) Pero el Gobierno - repitámoslo- también dirige la política mediante el ejercicio de la potestad reglamentaria, a través de la que desarrolla y concreta las leyes. Es decir, el Gobierno, además de impulsar el trabajo legislativo haciendo uso de la iniciativa, complementa el resultado final de ese trabajo por intermedio de actos de creación jurídica secundaria. Esta insistencia en la potestad reglamentaria gubernamental tiene por objeto comprender en qué consiste el control parlamentario de «la acción del Gobierno» mencionado en el artículo 66.2, pues, en efecto, dicho control se articula en una serie de técnicas destinadas a verificar el ejercicio de la dirección de la política. Lo que las Cortes pretenden con el control es, en definitiva, impulsar al Gobierno a hacer uso de la iniciativa legislativa o instarle a utilizar la potestad reglamentaria; de esta manera, mientras el Gobierno impulsa la creación jurídica primaria (que compete a las Cortes), las Cortes impulsan al Gobierno tanto a cumplir su papel activador de la creación primaria cuanto a ejercitar la creación secundaria. Sólo que en la forma parlamentaria de gobierno los dos impulsos no coinciden normalmente, porque el generado por el Gobienno se ajusta al programa aprobado por la mayoría, mientras que el parlamentario suele proceder de la oposición. En realidad, únicamente cuando el control parlamentario amenaza con desembocar en la exigencia de responsabilidad política - $\mathrm{y}$ eso sucede cuando la mayoría trata de que el Gobierno mantenga o altere su programa inicial- reviste auténtico carácter impulsor de la dirección política.

${ }^{67}$ Cfr. Cuocolo, op. cit., pág. 628. Escribe Spagna-Musso que en la forma de gobierno parlamentaria el Gabinete ejerce la dirección de la mayoría de la Cámara y, por tanto, de la actividad legislativa de esta última; de lo que se desprende que, si el sistema funciona regularmente, las proposiciones llegan a buen fin si reciben el apoyo del Gabinete. En consecuencia, la iniciativa parlamentaria no compite con la gubernamental, sino que la integra y estimula: cuando procede de la mayoría no puede contradecir el programa del Gobierno que ha obtenido su confianza; cuando surge de la minoría, o se acomoda a dicho programa o resulta estéril; en ambos supuestos, reviste un carácter secundario (cfr. op. cit., págs. 6263). Para las distorsiones que sufre la forma de gobierno parlamentaria cuando la iniciativa de las Cámaras pierde ese carácter, cfr. ibíd., págs. 63 y sigs., y el mismo Cuocolo, ibíd., loc. cit., Es más, concluye Spagna-Musso, si una proposición consigue, en contraste con la voluntad gubernamental, traducirse en ley, se producirá una degeneración en sentido asambleario de la forma de gobierno parlamentaria (cfr. ibíd., págs. 201-202). 